\title{
Host immune response and pathological expression in malaria: possible implications for malaria vaccines
}

\author{
G. E. GRAU, G. DEL GIUDICE and P.-H. LAMBERT \\ World Health Organization Immunology Research and Training Centre, Department \\ of Pathology, University of Geneva, CMU, 1 rue Michel-Servet, \\ $\mathrm{CH}-1211$ Geneva 4, Switzerland
}

INTRODUCTION

Recent progress in parasite immunobiology has led to the identification of several plasmodial antigens representing the target of the protective antibody response of the infected host. As a consequence, some of these antigens have been envisaged as potential malaria vaccines in man. However, in spite of these achievements, the fine mechanisms which lead to the development of a state of partial protective immunity or to the triggering of immunopathology during malaria infection are not yet fully understood. Thus, it may be appropriate to evaluate the relative importance of individual host immune responsiveness to parasite epitopes involved in the induction of immunity, or of some immunologically mediated adverse reactions such as glomerulonephritis, anaemia, thrombocytopenia, and cerebral syndrome.

We have addressed this question using two differing approaches. First, the role of the genetic background of the host in regulating the intensity of the immune response against the repetitive epitope of Plasmodium falciparum circumsporozoite (CS) protein was studied. Second, the involvement of immune mechanisms in some complications of malaria, such as cerebral manifestations and thrombocytopenia, were investigated, with particular attention to the role played by certain $T$ cell subsets.

HOST IMMCNE RESPONSE TO PLASMODIUM EPITOPES: CAN GENETIC

RESTRICTION LIMIT THE EFFECTIVENESS OF FUTURE MALARIA VACCINES?

It was shown in experimental animal models and in human volunteers that inactivated malaria parasites were able to confer immune protection against infectious challenges (reviewed by Cochrane, Nussenzweig \& Nardin, 1980). The production of monoclonal antibodies directed against plasmodial antigens and the progress achieved in molecular biology led to the characterization of several antigens able to confer some degree of immune protection against malaria infection (reviewed by Drager-Dayal \& Lambert, 1986).

One of the most extensively studied malaria antigens is the circumsporozoite (CS) protein. Individuals living in malaria-endemic areas produce antibodies against these proteins after natural malaria infections and the anti-sporozoite antibody titres increase as a function of age: children under 2 years of age are mostly negative whereas the great majority of adults over 40 years are positive (Nardin et al. 1979; Tapchaisri et al. 1983; Zavala, Tam, Nussenzweig \& Nussenzweig; $1985 a$; Del Giudice et al. 1986a, $b$ ).

The CS proteins consist of an amino acid sequence tandemly repeated several times and flanked by unrepeated sequences (reviewed by Nussenzweig \& Nussenzweig, 1985). Most monoclonal antibodies so far produced against sporozoites and most antisporozoite antibodies induced after natural malaria infections bind specifically to the 
repeated amino acid sequence (Zavala, Cochrane, Nardin, Nussenzweig \& Nussenzweig, 1983).

The repetitive epitope of $P$. falciparum CS protein consists of 4 amino acids $($ Asn-Ala-Asn-Pro $=$ NANP) repeated 37 times (Dame et al. 1984; Enea et al. 1984). $(\mathrm{NANP})_{n}$ sequences have been now produced by both chemical synthesis (Zavala $\mathrm{et}$ al. $1985 b$; Ballou et al. 1985) and by recombinant DNA technology (Young et al. 1985). It has been shown that 3 (NANP) repeats represent the minimal size of the molecule able to be recognized efficiently by specific antibodies (Zavala et al. $1985 \mathrm{~b}$ ) and to prime specifically murine 'T cells in vivo (Togna et al. 1986). (NANP) ${ }_{n}$ peptides have been successfully employed for the detection of anti- $P$. falciparum sporozoite antibodies by means of enzyme-linked immunosorbent assay (Del Giudice et al. 1986 a; Hoffman et al. 1986) or radio-immunometric assay (Zavala, Tam \& Masuda, 1986). A large (NANP) ${ }_{40}$ synthetic peptide was used as coating antigen for ELISA in a longitudinal study carried out in a rural community in Tanzania (Del Giudice et al. 1986b). It was found that, at 10 years of age, about half of the children who have been heavily exposed to malaria infections did not develop anti-NANP antibodies. Furthermore, considerable differences in antibody levels against NANP were observed in children living in different households but exposed to the same epidemiological conditions, although their antibody titres to asexual blood-stage antigens were similar. These data suggested that the genetic background may be of particular importance for the regulation of anti-sporozoite responses. $(\mathrm{NANP})_{n}$ synthetic peptides conjugated to carrier proteins and large recombinant peptide carrying an amino acid sequence of $E$. coli. were shown to be highly immunogenic in mice and rabbits: the antibodies raised against them recognized specifically $P$. falciparum sporozoites and inhibited the penetration of sporozoites into cultured hepatoma and hepatic cells and their maturation into exo-erythrocytic forms (Mazier et al. 1986).

The immunogenicity of $(\mathrm{NANP})_{n}$ sequences could be directly studied in our laboratories, both at $\mathrm{T}$ and $\mathrm{B}$ cell levels, using a novel large synthetic peptide consisting of $40(\mathrm{NANP})$ repeats, $(\mathrm{NANP})_{40}$, without any carrier. $\mathrm{C} 57 \mathrm{BL} / 6 \mathrm{mice}\left(\mathrm{H}-2^{\mathrm{b}}\right)$ responded strongly to $(\mathrm{NANP})_{40}$, producing high titres of IgG and IgM antibodies which also recognized specifically extracts of Anopheles stephensi mosquitoes infected with $P$. falciparum sporozoites. Congenic mice bearing the immunoglobulin allotype $\mathrm{Ig}^{\mathrm{e}}$ responded in the same manner, as well as the $(\mathrm{C} 57 \mathrm{BL} / 6 \times \mathrm{BALB} / \mathrm{c}) \mathrm{F} 1$ hybrid mice. However, neither athymic C57BL/6 $n u / n u$ nor congenic C57BL/6.H-2 ${ }^{\mathrm{k}}$ mice produced anti-(NANP) $)_{40}$ antibodies (Del Giudice et al. $1986 c$ ). These results suggested that the production of antibodies to carrier-free $(\mathrm{NANP})_{n}$ peptides (i) $\mathrm{T}$ cell dependent, (ii) not dependent on the immunoglobulin allotype of mice and (iii) possibly linked to particular haplotypes of the murine major histocompatibility complex (MHC) H-2.

In addition, 14 mouse strains bearing 9 different $\mathrm{H}-2$ haplotypes were immunized with $(\mathrm{NANP})_{40}$ without carrier but, surprisingly, only $\mathrm{H}-2^{\mathrm{b}}$ mice $(\mathrm{C57BL} / 6, \mathrm{C57} \mathrm{BL} / 10$ and $\mathrm{BXSB}$ ) were able to mount a strong antibody response against the peptide, all non- $\mathrm{H}-2^{\mathrm{b}}$ mouse strains tested being completely unresponsive (Fig. 1). The anti-(NANP) antibody response was shown to be strictly linked to the presence of the $b$ allele in the I-A region of the $\mathrm{H}-2$ gene complex (Del Giudice et al. 1986c). In fact, only $\mathrm{I}-\mathrm{A}^{\mathrm{b}}$ recombinant B10.A $(5 R)$ mice produced such antibodies. Furthermore, the antibody response against $(\mathrm{NANP})_{40}$ was extremely weak in $\mathrm{B} 6 \mathrm{CH}-2^{\mathrm{bm12}}$ mutant mice, which carry a gene conversion leading to the substitution of 3 amino acids of the beta 1 domain of the $\mathrm{I}-\mathrm{A}^{\mathrm{b}}$ beta chain (McIntyre \& Seidman, 1984). These findings were confirmed by experiments employing (NANP)-specific $\mathrm{T}$ cell clones derived from lymph node cells of C57BL/6 


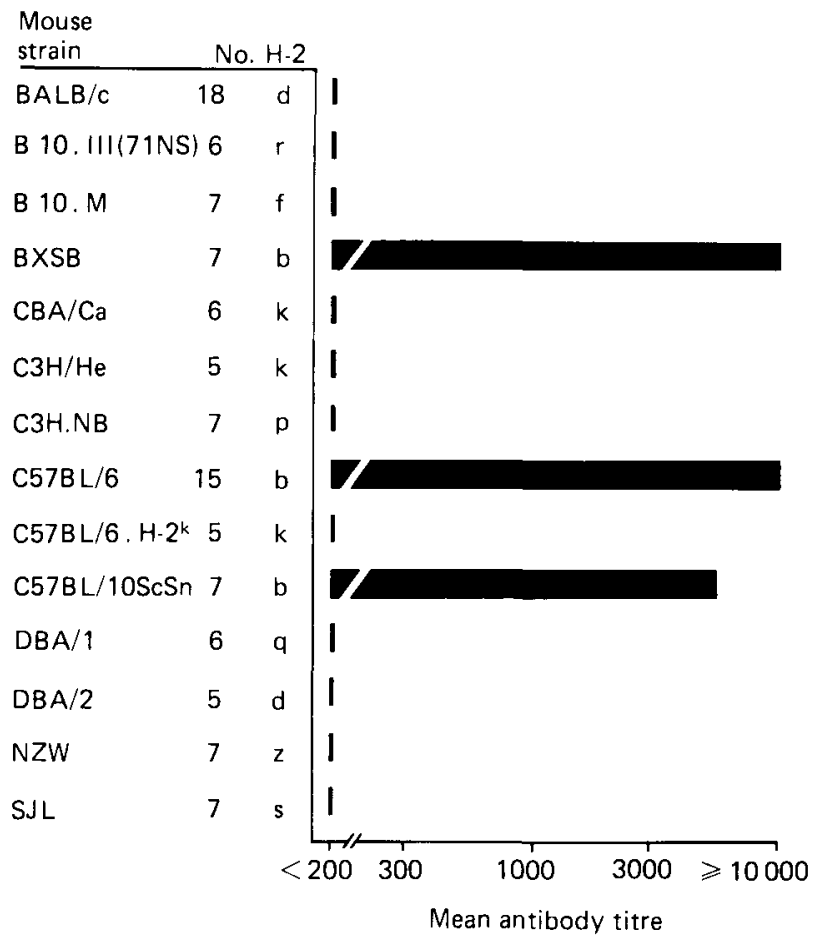

Fig. 1. IgG antibody response against $\left(\mathrm{NANP}_{\mathbf{4} 0}\right.$ in 14 mouse strains bearing 9 different $\mathrm{H}-2$ haplotypes. Mice were immunized at the base of the tail with $50 \mu \mathrm{l}$ of $(\mathrm{NANP})_{40}(20 \mu \mathrm{g})$ in Complete Freund's Adjuvant. Four weeks later the mice were boosted in the same way with the peptide in Incomplete Freund's Adjuvant. Sera were taken 7 days later and tested individually by ELISA. employing $(\mathrm{NANP})_{40}$ at a concentration of $1 \mu \mathrm{g} / \mathrm{ml}$ for coating the plates. Solid bars represent the geometrical mean of the titres obtained in each group. Titres of less than $1: 200$ were considered to be negative.

mice immunized with carrier-free $\left(\mathrm{NANP}_{40}\right.$ (Togna et al. 1986). These $\mathrm{L} 3 \mathrm{~T} 4^{+} \mathrm{T}$ cell clones proliferated only in the presence of irradiated spleen cells from $\mathrm{C} 57 \mathrm{BL} / 6$ or B10.A(5R) mice as antigen presenting cells (APCs), not in the presence of APCs from B10.A $(4 \mathrm{R})$ nor from $\mathrm{B} 6 \mathrm{CH}-2^{\mathrm{bm} 12}$ mice. $\mathrm{T}$ cell clone proliferation was specifically inhibited by adding an anti-I-A $\mathrm{A}^{\mathrm{b}}$ monoclonal antibody to the cultures. A similar genetic restriction of the immune response to NANP, at the $\mathrm{T}$ cell level, was recently reported by Good et al. (1986). The inability to respond to $(\mathrm{NANP})_{40}$ could be overcome in non- $\mathrm{H}-2^{\mathrm{b}}$ mice when they were immunized with the peptide conjugated to a carrier protein (Del Giudice et al. 1986c).

Thus, the murine antibody response to $(\mathrm{NANP})_{n}$ is genetically restricted and strictly linked to the presence of a particular allele $(b)$ in the I-A region of the $\mathrm{H}-2$ complex. This exceptional restriction is surprising since, usually, mice of more than one $\mathrm{H}-2$ haplotype are able to respond to a given epitope (reviewed by Schwartz, 1986). One can postulate that an analogous genetic control of the antibody response to (NANP) peptides could also exist in man, and may limit the effectiveness of a vaccination with the $(\mathrm{NANP})_{n}$ peptides. On the other hand, such genetic control could also exist for the antibody response to whole $P$. falciparum sporozoites. This could also explain the observation that a significant percentage of young subjects living in malaria endemic areas do not develop anti-NANP antibodies (Zavala et al. 1985a; Del Giudice et al. 
$1986 a, b)$. Further studies are required in order to determine the actual role played by MHC gene products in man in controlling the ability of different individuals to respond to sporozoites and/or to sporozoite peptides.

It was shown that the H-2 restriction existing towards the immunodominant repetitive epitope of $P$. falciparum CS protein is overcome when a peptide-carrier protein conjugate is employed as an immunogen. In these conditions, there is an expansion of $B$ cells specific for the repetitive epitope, but often no priming of NANP-specific T cells. Thus, individuals vaccinated with such conjugates may lack sporozoite-specific $T$ cells and, in endemic countries, would not benefit entirely from the boosting effect provided by natural sporozoite inoculations.

CAN MALARIA VACCINES ENHANCE IMMUNOPATHOLOGY? EVIDENCE FOR IMMUNOLOGICAL MECHANISMS IN SOME COMPLICATIONS OF EXPERIMENTAL MALARIA

In view of the presently available immuno-epidemiological data, it is conceivable that any future malaria vaccines would only confer partial immunity against plasmodium infection and one should expect a lack of vaccine efficiency in at least a small proportion of immunized children. Therefore, it may be essential to evaluate the relative risk of enhancing immunopathology by inducing an immune response towards selected plasmodial epitopes before natural exposure to malaria infection. This concern is largely based on experimental evidence suggesting that some major complications of malaria could partly result from the immune response against parasite antigens. This is particularly the case for glomerulonephritis, anaemia, thrombocytopenia, cerebral malaria and tropical splenomegaly syndrome.

The pattern of individual immune responses, particularly at the $\mathrm{T}$ cell level, and the relative involvement of certain identified plasmodium antigens have been studied in our laboratory in relation to the development of some of these pathological reactions during murine malaria.

\section{Cerebral malaria}

Cerebral symptoms accompanying acute falciparum malaria in young children and in non-immune adults represent severe complications with a frequent fatal outcome. The most common autopsy findings are vascular congestion and plugging of blood vessels with heavily parasitized erythrocytes, petechial haemorrhages and reactive gliosis (Polder, Jerusalem \& Eling, 1983). The neurons usually show no obvious lesions besides signs of anoxia associated with localized cerebral oedema in the perivascular areas. Brain oedema is a common finding at autopsy (Aikawa, Suzuki \& Gutierrez, 1980). However, recent studies have shown by computed tomography that cerebral oedema may occur but is not a consistent feature of severe cerebral malaria (Looaresuwan et al. 1983). In vivo damage to the endothelial cell, with resulting alteration of capillary permeability has been reported in patients with cerebral malaria (Areekul. Kasemsuth \& Kanakakorn, 1984) and increased permeability of the choroid plexus has been shown in rodent malaria (Depierreux, Hochmann, Herrera \& Lambert, 1986). The pathogenesis of these charges remains unknown, although various hypotheses have been proposed: endothelial lesions (Knisely, 1961; Wash, 1979), with attachment of monocytes to the endothelium (Rest \& Wright, 1979; Rest, 1982); sequestration of parasitized red blood cells in capillaries (Yoeli \& Hargreaves, 1974; McPherson et al. 
1985 ); allergic reaction of the central nervous system to antigenic challenge (Toro \& Roman, 1978); T-cell-mediated cellular immune reaction (Wright, Masembe \& Bazira, 1971 ; Finley, Mackey \& Lambert, 1982) or T-cell-dependent humoral reaction involving circulating immune complexes (Contreras, June, Perrin \& Lambert, 1980; Rest \& Wright, 1979; Adam et al. 1981) and the activation of the complement cascade.

In man, indirect evidence of a $\mathrm{T}$ cell involvement in neurological complications is provided by the observation of lower frequency of cerebral malaria in malnourished children (Edington, 1967). Thymic atrophy (Watts, 1969; McFarlane, 1971) and functional impairment of cell-mediated responses (McMurray, 1984) have been documented. Immune mechanisms, and particularly $\mathbf{T}$ cell mediated immunity have been implicated in the development of experimental cerebral malaria, since neurological complications are less severe in neonatally thymectomized hamsters (Wright et al. 1971) and absent in athymic nude BALB/c mice (Finley et al. 1982).

In our laboratory, a mouse model of cerebral malaria, after infection with Plasmodium berghe $i$ asexual blood stages, was analysed. In this experimental model, a cumulative mortality of about $90 \%$ between day 7 and day 15 of infection was observed in CBA mice, which appeared to be genetically susceptible to the development of neurological lesions. A particularly important feature of this model is that cerebral signs occurred when anaemia was moderate and the parasitaemia relatively low. In addition, several clinical and histopathological parameters were found to be similar to those observed in patients with cerebral malaria (Jerusalem et al. 1983; Grau et al. 1986). Three lines of evidence indicate that helper $\mathrm{T}$ ly mphocytes play a significant role in the development of murine cerebral malaria (Grau et al. 1986).

First, it was demonstrated that the in vivo depletion in $\mathrm{L}^{\mathrm{TT}} 4^{+}$helper/inducer $\mathrm{T}$ cells induced by treatment of $P$. berghe $i$-infected mice with an IgG2b monoclonal antibody (MAb) directed against the L3T4 molecule, completely abrogated the occurrence of cerebral malaria, although there was no modification of the infection itself (Grau et al. 1986). No protective effect was seen after treatment of infected mice with a MAb of the same isotype directed against Ly. $2^{+} \mathrm{T}$ cell subset. The effectiveness of this treatment by anti-L3T4 MAb in infected mice was demonstrated both phenotypically (depletion of the corresponding $\mathrm{T}$ cell subset) and functionally (inhibition of the IgG antibody response to a $\mathrm{T}$-dependent antigen, tetanus toxoid).

Second, experiments were conducted in adult-thymectomized, irradiated and bone marrow-reconstituted $(\mathrm{A} T \times \mathrm{BM}) \mathrm{CBA}$ mice which appeared to be completely resistant to the development of neurological lesions upon infection with $P$. berghei. These results confirmed and extended the results obtained using athymic $n u / n u$ mice (Finley et al. 1982) which suggested a role for $T$ cells in the development of cerebral malaria. $T$ cells carrying the L3T4 phenotype were shown to be particularly involved in this syndrome since reconstitution of $\mathrm{AT} \times \mathrm{BM}$ CBA mice with normal $\mathrm{L3T}^{+} \mathrm{T}$ cells rendered these mice fully susceptible to the development of neurological complications. In contrast, $\mathrm{AT} \times \mathrm{BM}$ mice reconstituted with the Ly. $2^{+} \mathrm{T}$ cell subset did not die acutely with neurological signs but later developed severe anaemia and overwhelming parasitaemia (Grau et al. 1986).

Third, there was an exacerbation of neurological signs and earlier mortality observed after transfer of $\mathrm{L3T4}^{+} \mathrm{Ly} .2^{-} \mathrm{T}$ cells from mice with cerebral malaria into infected euthymic mice. This observation supported the hypothesis of an involvement of these cells in the pathogenesis of cerebral malaria.

Humoral parameters of the immune reponse were also analysed in $P$. berghe $i$-infected CBA mice (Grau et al. 1986). As previously suggested (Rosenberg, 1978; Finley et al. 


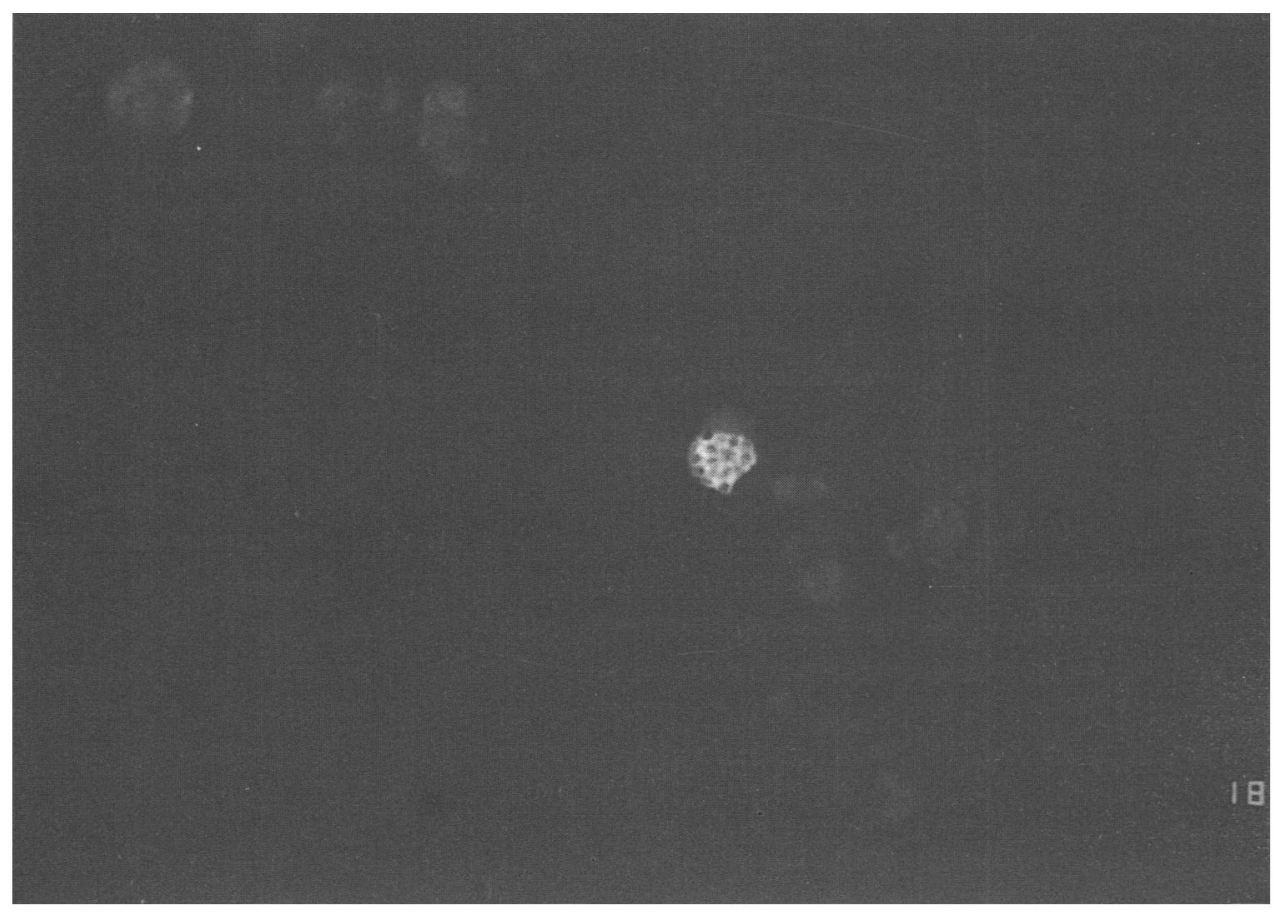

Fig. 2. Detection, by indirect immunofluorescence, of specific antibodies directed against segmented schizonts in the serum of a Plasmodium berghei-infected CBA mouse developing cerebral malaria 9 days after infection.

Table 1. Effects of T-cell depletion or reconstitution on anti-Plasmodium antibody response during infection.

\begin{tabular}{lccc} 
& \multicolumn{2}{c}{ Anti-Plasmodium antibodies } \\
\cline { 2 - 4 } & & \multicolumn{2}{c}{ Specificity } \\
\cline { 2 - 4 } Mice & IFA titre* & $\mathrm{RF}, \mathrm{TZ}$ & Seg. SZ \\
Euthymic & 8173 & + & + \\
$\begin{array}{l}\text { Euthymic } \\
\quad \text { anti-L3T4 MAb }\end{array}$ & 469 & + & - \\
$\quad$ anti-Ly.2 MAb & 729 & + & + \\
$\mathrm{AT} \times \mathrm{BMI}$ & 420 & + & - \\
$\mathrm{AT} \times \mathrm{BMI} .^{+}$ & 3040 & + & + \\
$\mathrm{AT} \times \mathrm{BM} 2^{+}$ & 420 & + & - \\
& $*$ Day 14. & &
\end{tabular}

1982) malaria-associated polyclonal $B$ cell activation was found to be $T$ cell dependent. Indeed. in infected mice treated with anti-L3T4 MAb, there was a marked inhibition of the increase in serum levels of $\operatorname{IgG}, \mathrm{IgM}$ and circulating immune complexes (CIC) compared with untreated infected animals. The specific anti-plasmodium immune response was also studied, with particular attention to antibodies recognizing certain stages of parasite development (Fig. 2, Table 1). In fact, in malaria-infected mice treated with anti-L3T4 MAb, there was a significant decrease of the specific anti-plasmodium antibody response but this response was in no way completely suppressed. The quality 
of the response appeared to be more specifically influenced by the treatment with anti-L3T4 MAb. Antibodies directed against mature stages of plasmodium (polysegmented schizonts) were consistently absent in the sera from those $\mathrm{L} 3 \mathrm{~T} 4^{+} \mathrm{T}$ cell-depleted mice which were protected against cerebral malaria (Table 1). Moreover, anti-segmented schizont antibodies were found in only 1 of 15 sera from day 8 -infected euthymic CBA mice without cerebral malaria. The absence of anti-segmented-schizont immune response in the anti-L3T4 treated mice might be of importance in the protecting effect of this treatment.

In addition, the hypergammaglobulinaemia and the increase in CIC levels, which were absent in $\mathrm{AT} \times \mathrm{BM}$ mice, were restored in $\mathrm{A} \mathrm{T} \times \mathrm{BM}$ mice reconstituted with normal $\mathrm{L3T}^{+}{ }^{+} \mathrm{T}$ cells $\left(\mathrm{AT} \times \mathrm{BM} .4^{+}\right)$. Specific antibody levels indicated that $\mathrm{AT} \times \mathrm{BM}$ mice responded quite poorly to malaria antigens. Although this response was only moderately enhanced by the adoptive transfer of $\mathrm{L} 3 \mathrm{~T} 4^{+} \mathrm{T}$ cells, it is noteworthy that this transfer led to the appearance of anti-segmented schizont antibodies, already detectable by day 10 .

The data presented here indicate that experimental cerebral malaria is probably mediated by immune mechanisms. Indeed, it was shown that the development of murine cerebral malaria is not directly related to the degree of anaemia and parasitaemia, but rather appears as the expression of immunopathological reactions of the infected host. The importance of the functional integrity of lymphoid cells expressing the L3T4 phenotype (helper $\mathrm{T}$ cells) in the triggering of neurological complications was outlined in these studies. One should note that L3T4 ${ }^{+} \mathrm{T}$ cells of different specificities for malaria antigens may have different effects on the infection and, particularly, on the cerebral complications.

Various functional relationships between $\mathrm{L3T4}^{+} \mathrm{T}$ cells and neurological lesions can be envisaged (Fig. 3). Firstly, the helper effect of $\mathrm{L3T}^{+}{ }^{+} \mathrm{T}$ cells for the specific anti-plasmodium antibody response may be of particular importance, since it was shown that antibodies of certain specificities (segmented schizont antigens) are consistently associated with the occurrence of cerebral malaria. This helper effect may also be exerted in a less specific manner: malaria-associated polyclonal B-cell activation appears indeed to be largely $\mathrm{T}$ cell dependent. Secondly, the activation of $\mathrm{T}$ cells in the presence of properly presented malarial antigens results in the release of various lymphokines such as interleukin 2 , interleukin 3 , colony-stimulating factor and $\gamma$-interferon. The production of $\gamma$-interferon was demonstrated in vitro by $\mathrm{T}$ cells in the presence of macrophages and parasitized erythrocytes (Ockenhouse, Schulman \& Shear, 1984). 'This was associated with the release of reactive oxygen species, participation of which has been documented in acute vascular changes (Chan, Schmidley, Fishman \& Longar, 1984) and suggested in the pathogenesis of cerebral malaria (Clark \& Hunt, 1983; Clark, Hunt \& Cowden, 1987). Tumor-necrosis factor (TNF) is another intermediate produced upon macrophage activation which is known to alter selectively endothelial cell functions (Nawroth et al. 1986). Thirdly, L3T4 ${ }^{+} \mathrm{T}$ cells can also mediate delayed-type hypersensitivity (DTH). However, the existence of local DTH-like reactions in the cerebral compartment was not suggested by histological studies since there was no accumulation of lymphocytes at the site of brain lesions (Jerusalem et al. 1983; MePherson et al. 1985; Depierreux et al. 1986).

The relevance of these data to human pathology should be discussed. Indeed, it has been suggested that immune mechanisms are not involved in the pathogenesis of human cerebral malaria (see Warrell, this issue) because there was no evidence, at autopsy, of cellular infiltrates nor of visible endothelial damage in the brain (McPherson et al. 1985). 


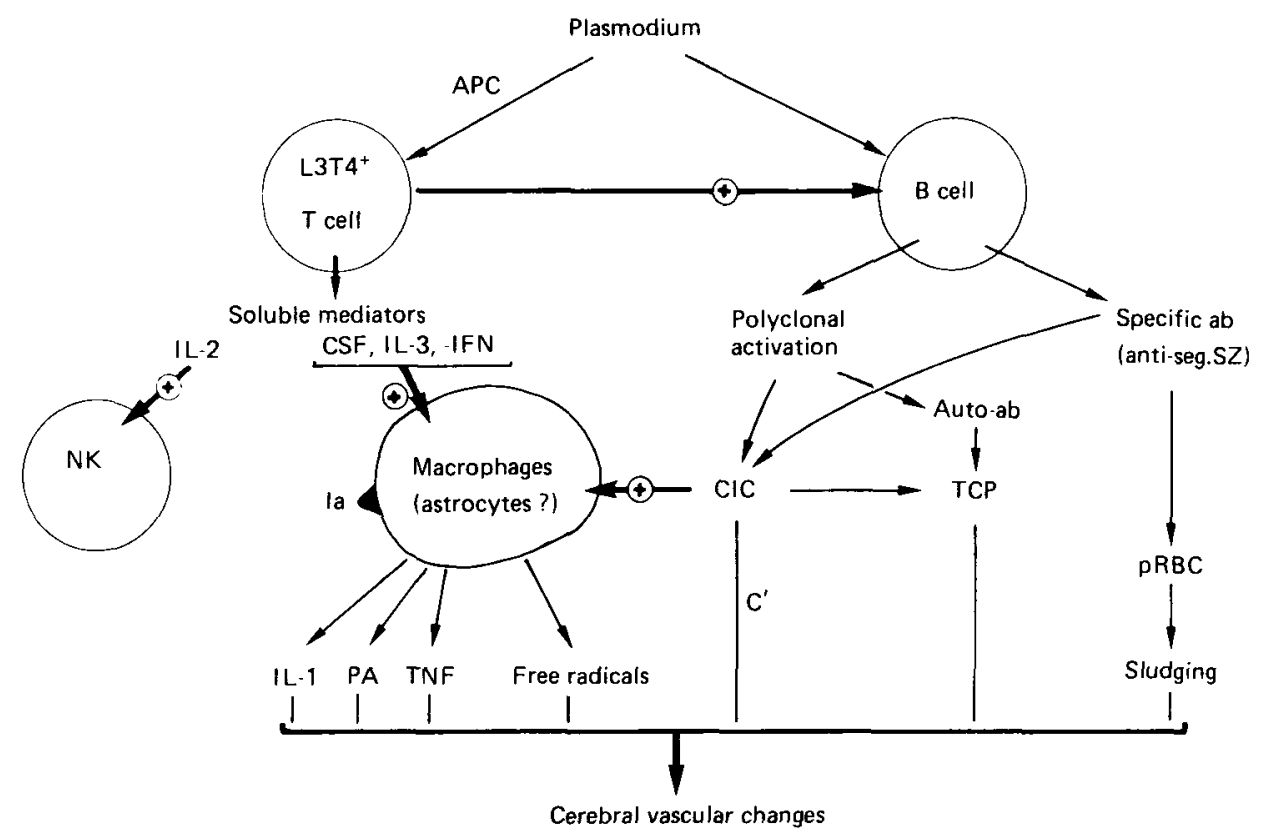

Fig. 3. Schematic representation of various mechanisms by which $\mathrm{L} 3 \mathrm{~T} 4^{+} \mathrm{T}$ cells can lead to the triggering of cerebral vascular changes (see text for discussion). APC, antigen presenting cell; CSF, colony-stimulating factor; seg. SZ, segmented schizonts; CIC, circulating immune complexes; TCP, thrombocytopenia; $p$ RBC, parasitized red blood cells; PA. plasminogen activator; TNF, tumour necrosis factor.

In our experiments in mice, there were no lymphoid cell infiltrates in the brain and the vascular lesions were acute and localized to certain cerebral territories. Obviously, the sole classical morphological analysis does not allow us to draw conclusions regarding the existence of immunopathological mechanisms. However, since all these lesions were prevented in mice with an impaired immune response and appeared again after restoration of the L3T4 ${ }^{+} \mathrm{T}$ cell compartment, indirect mechanisms dependent on the specific or non-specific immune response to malaria are probably involved in the pathogenesis of the syndrome in mice. One cannot exclude the possibility that similar indirect mechanisms are also responsible for the cerebral syndrome in man.

\section{EFFECTS OF CYCLOSPORIN A ON CEREBRAL MALARIA}

Cyclosporin A (CsA) is an immunosuppressive agent capable of interfering at several levels with the immune response (Borel, Feurer, Magnee \& Staehelin, 1977; Larsson, 1980; Bunjes, Hardt, Rollinghof \& Wagner, 1981 ; Shevach, 1985). The T cell specificity for the immunosuppressive effects of $\mathrm{CsA}$ was suggested by the failure of CsA to suppress antibody response to bacterial lipopolysaccharide antigens in vivo in nude mice. Recent data suggest that the major site of action of $\mathrm{CsA}$ is the inhibition of $\mathrm{mRNA}$ transcription for the lymphokines interleukin 2 (IL-2), interleukin 3 (IL-3) and interferon- $\gamma$ (IFN- $\gamma$ ) (Kronke et al. 1984; Elliott et al. 1984; Granelli-Piperno, Inaba \& Steinman, 1984; Wiskocil et al. 1985). CsA inhibits lymphokine production in both helper and cytolytic cells, but does not directly inhibit or block proliferative responses of cytolytic cells in which proliferation can occur via an IL-2 independent pathway (Herold et al. 1986). Because of the powerful inhibitory effects of CsA on helper $\mathrm{T}$ cells and since these helper 
T cells have been shown to play a major role in the pathogenesis of murine cerebral malaria, the potentially beneficial effects of $\mathrm{CsA}$ were evaluated in the murine model of $P$. berghei infection.

A direct toxic effect of CsA on malaria parasite has been documented (ThommenScott, 1981; Nickell, Scheibel \& Cole, 1982). CsA has therefore been administered at different doses, especially at doses unable to exert any anti-parasite effect. It was shown that, in these conditions, $\mathrm{CsA}$ as well as some $\mathrm{CsA}$ analogues were able to protect fully more than $90 \%$ of treated animals (Grau et al. manuscript submitted). As little as $1 \mathrm{mg}$ $\mathrm{CsA} / \mathrm{kg}$ body weight, given during 5 consecutive days once the infection had entered its patent phase, displayed a strong protective effect on cerebral complications without interfering at all with the progression of parasitaemia and without any detectable effect on humoral immune responses. Higher doses of CsA delayed the increase of parasitaemia and, as a consequence, cerebral malaria was delayed but in no way prevented as in mice treated with lower doses. The mechanisms by which low doses of CsA exert their protective effects on cerebral complications are not yet understood, but the in vivo evaluation of post-translational inhibition of $\mathrm{mRNA}$ for various lymphokines is under current investigation.

These results provide promising implications for treatment of malaria-infected patients, with or without severe complications. Preliminary results have indicated (J. F. Borel, personal communication) a beneficial effect of CsA in human patients with cerebral malaria. This observation tends to support the hypothesis of an immunopathogenesis of cerebral malaria.

MALARIA-ASSOCIATED THROMBOCYTOPENIA

Thrombocytopenia is a frequent complication in patients with severe malarial infection (Beale, Cormack \& Oldrey, 1972; Butler et al. 1973; Horstmann, Dietrich, Bienzle \& Rasche, 1981; Wilson, Neame \& Kelton, 1982).

The mechanism of this thrombocytopenia remains poorly understood. The rapidity of onset and recovery as well as reduced platelet survival (Skudowitz et al. 1973; Horstmann et al. 1981) suggests that it is caused by increased platelet destruction. Disseminated intravascular coagulation (DIC) has been considered as a possible cause in some investigations (Dennis, Eichelberger, Inman \& Conrad, 1967; Borochowitz, Crosley \& Metz, 1970) but, in recent years, it has been recognized that thrombocytopenia is a very common and early sign of malaria infection, whereas DIC is distinctly uncommon (Beale et al. 1972; Srichaikul et al. 1975; Vreken \& Cremer-Goote, 1978). Direct interactions between plasmodium and platelets have also been suggested. Parasites have been demonstrated inside blood platelets by electron microscopy in both human and experimental infections (Fajardo, 1973; Fajardo \& Tallent, 1974; Fajardo, 1979 ), but the precise implications of this finding remain obscure. Immune mechanisms may also mediate thrombocytopenia and can be potentiated by the generalized reticulo-endothelial system (RES) hyperplasia found at autopsy and the increased RES functional activity during acute malaria (Sheagren, Tobie, Fox \& Wolfe, 1970). Immune complexes which are present in the circulation of malaria-infected patients could play a role in the peripheral destruction of platelets as well as red blood cells (Contreras et al. 1980). Some evidence for such immune mechanisms has been provided by the quantification of platelet-associated IgG (PAIgG) in patients with acute malaria infection. Increased PAIgG levels are thought to be responsible for the rapid clearance 
of circulating platelets by the RES and are currently considered to be a criterion for definition of immune thrombocytopenia (Kelton \& Gibbons, 1982). Kelton, Keystone, Proctor \& Neame (1980) reported increased levels of PAIgG in the majority of patients with malaria and thrombocytopenia. PAIgG returned to normal as the parasites were cleared from the circulation and the platelet counts returned to normal values. Recently, Kelton et al. (1983) demonstrated that, in patients with P. falciparum malaria and thrombocytopenia, IgG binds to platelet-associated malarial antigens through its Fab terminus, probably representing anti-platelet antibodies.

In our mouse model of infection with $P$. berghei asexual blood stages, thrombocytopenia develops as early as day 4 and its severity increases gradually until death.

Thrombocytopenia associated with $P$. berghei infection is likely to be due to an increased peripheral destruction rather than a central hypoproduction of platelets, since in infected mice, bone-marrow megakaryocytes were found in increased numbers and the survival time of ${ }^{111}$ Indium-labelled platelets was reduced (Grau et al. manuscript submitted). The role of immune mechanisms was confirmed by the observation of increased amounts of IgG on platelets from infected animals. Elevated PAIgG correlated inversely with platelet counts. In addition, it was shown that serum from infected mice contains anti-platelet antibodies, as measured by an enzyme-linked immunosorbent assay (ELISA) using platelet monolayers as the solid phase (Grau et al. manuscript submitted). This assay was shown to be independent of the binding of circulating immune complexes through the Fc receptor. The functional in vivo importance of these serum anti-platelet antibodies was outlined by the fact that passive transfer of ultracentrifuged serum from $P$. berghe $i$-infected, thrombocytopenic mice led to an immediate drop in platelet counts in syngeneic recipients (Grau et al. manuscript submitted).

The occurrence and the degree of $P$. berghei-induced thrombocytopenia was found to be dependent upon the $T$ cell status of the host. Indeed, treatment of infected mice with an IgG2b MAb directed against the L3T4 surface antigen protected these mice against thrombocytopenia. In contrast, treatment with anti-Ly.2 MAb of the same isotype had no protective effect on thrombocytopenia. Similarly, there was no significant thrombocytopenia in AT $\times$ BM mice infected with $P$. berghei. The $\mathrm{T}$ cell dependency of $P$. berghe $i$-induced thrombocytopenia was further demonstrated in experiments using $\mathrm{AT} \times \mathrm{BM}$ mice selectively reconstituted with normal $\mathrm{L}_{3} \mathrm{~T}^{+}$or $\mathrm{Ly} .2^{+} \mathrm{T}$ cell subpopulations. Indeed, the susceptibility to develop thrombocytopenia upon infection with $P$. berghei was restored only in $\mathrm{AT} \times \mathrm{BM}$ mice previously reconstituted with $\mathrm{L} 3 \mathrm{~T} 4^{+}$ $\mathrm{T}$ cells. More direct evidence of the role of L3T4 T cells in the development of $P$. berghe $i$ induced thrombocytopenia was provided by another transfer. $\mathrm{L}_{3} \mathrm{~T}^{+} \mathrm{Ly} .2^{-} \mathrm{T}$ cells were isolated from $P$. berghe $i$-infected mice undergoing cerebral malaria and severe thrombocytopenia. After elimination of contaminating parasitized erythrocytes, these cells were adoptively transferred to normal syngeneic recipients and were able to elicit a significant degree of thrombocytopenia.

Apart from antibody-mediated mechanisms, interactions between lymphoid cells and platelets have been described in vitro (Coeugniet, 1979; Gengozian \& Rice, 1982) and might also play a role in the effect observed in such cell transfer experiments. Taken together, these results indicate that, in this experimental model, the thrombocytopenia which occurs during malaria infection displays all the parameters of an immunopathological complication. It is noteworthy that, in T cell-depleted mice, such as anti-L3T4, monoclonal antibody-treated or $\mathrm{AT} \times \mathrm{BM}$ mice, the protection against thrombocytopenia paralleled the protection against cerebral malaria. Thrombocytopenia may thus conceivably represent one of the multiple factors possibly involved in the triggering of 
cerebral complications of malaria, by favouring the occurrence of brain haemorrhages (Fig. 3).

\section{CONCLUSION AND SUMMARY}

Until recently, the immune response to plasmodia has been considered without discriminating the relative importance of individual antigens or distinct epitopes in the induction of this response. It now appears that the general rules which regulate the operation of the immune system also apply to the immune responsiveness to single plasmodium epitopes. Thus the development of anti-parasite immunity, as well as the triggering of immunopathological manifestations, are probably strictly related to the variety of individual patterns of immune responsiveness encountered in populations exposed to the infection. These considerations are particularly relevant to the selection of antigens as potential candidates for malaria vaccination in order to achieve protecting efficiency without increasing the frequency of the well-known complications of acute malaria.

The immune response to $P$. falciparum CS protein repetitive epitope, NANP, is likely to be hampered by the requirement for an appropriate genetic background at the level of the MHC genes. This phenomenon was clearly shown in mice since only $\mathrm{I}-\mathrm{A}^{\mathrm{b}}$ mice were able to develop a proper $\mathrm{T}$ cell response and to produce anti-NANP antibodies after immunization with carrier-free peptide.

Preliminary epidemiological studies in man indicate that the repeated natural exposure to this epitope can induce an anti-NANP response but not in all individuals. Therefore, the relative importance of the genetic regulation of the immune response to defined plasmodium epitopes in man will have to be taken into account in order to avoid inefficient vaccination in a significant proportion of individuals at risk.

The analysis of experimental models of malaria in rodents underlines the potential risk of enhancing malaria-associated pathology by an inappropriate or a relatively inefficient immunization against selected plasmodium antigens. Indeed, $\mathrm{T}$ cells of the L3' $\mathrm{T}^{+}{ }^{+}$subset seem to play a central role in the pathogenesis of murine cerebral malaria as well as in malaria-associated thrombocytopenia. The immune response to certain asexual blood-form antigens may be critical for the pathological expression of the disease. Obviously, potentially pathogenic responses are also genetically controlled and possible vaccine side-effects may be restricted to a limited segment of the population. However, in view of the large numbers of individuals exposed to malaria and likely to be vaccinated, the risk of enhancing immunopathology should not be neglected.

This work was supported by CXDP/World Bank/WHO Special Programme for Research and Training in Tropical Diseases and by the Swiss National Foundation, grant No. 3.826.0.83.

\section{R E F E R E N C ES}

Ada. ( ‥ Geniteac, M., Golgerot-Pocinalo, M., Verroest, P., Lebras, J., Gibert, C. \& Morel-Maroger. L. (1981). Cryoglobulins, circulating immune complexes and complement activation in cerebral malaria. Infection and Immunity 31, 530-5.

Aikawa. II.. Stzcki, M. \& Gltierrez, Y. (1980). Pathology of malaria. In Malaria, vol. 3, (ed. J. P. Kreier). pp. 47-102. New York: Academic Press.

Areektl. S.. Kasmiscth, R. \& KanakakoRn, K. (1984). Studies on the transcapillary escape rate of fibrinogen and capillary permeability in patients with Plasmodium falciparum malaria. Tropical and Geographical Medicine 36. 151-7. 
Ballot, W. R., Rothbard, J., Wirtz, R. A., Gordox, D. M., Williams, J. L., Gore, R. W.. Schneider, I., Hollivgdale, M. R., Beaudoin, R. L., Maloy, W. L., Miller, L. H. \& HockMEYER, W. T. (1985). Immunogenicity of synthetic peptides from circumsporozoite proteins of Plasmodium falciparum. Science 228, 996-9.

Beale, P. J., Cormack, J. D. \& Oldrey, T. B. N. (1972). Thrombocytopenia in malaria with immunoglobulin ( $\operatorname{IgM})$ changes. British Medical Journal 1, 345-9.

Borochowitz, D., Crosley, A. L. \& Metz, J. (1970). Disseminated intravascular coagulation with fatal haemorrhage in cerebral malaria. British Medical Journal 2, 710.

Borel, J. F., Feurer, C., Magnee, C. \& Staehelis, H. (1977). Effects of the new antilymphocyte peptide Cyclosporin A in animals. Immunology 32, 1017-25.

Bunjes, D., Hardt, C., Rollinghoff, M. \& Wagner, H. (1981). Cyelosporin A mediates immunosuppression of primary cytotoxic T-cell responses by impairing the release of interleukin 1 and interleukin 2. European Journal of Immunology 11, 657-61.

Butler, T., Tong, M. J., Fletscher, J. R., Dostalek, R. J. \& Robbiss, T. O. (1973). Blood coagulation studies in Plasmodium falciparum malaria. American Journal of Medical Sciences 265. 63-7.

Chan, P. H., Schuidley, J. W., Fishman, R. A. \& Longar, S. M. (1984). Brain injury, edema, and vascular permeability changes induced by oxygen-derived free radicals. Neurology 34, 315-20.

Clark, I. A. \& Hunt, N. H. (1983). Evidence for reactive oxygen intermediates causing hemolysis and parasite death in malaria. Infection and Immunity 39, 1-6.

Clark, I. A., Hunt, N. H. \& Cowden, W. B. (1987). Immunopathology of malaria. In Immunology, Immunopathology and Immunoprophylaxis of Parasite Infections (ed. E. J. L. Soulsby). CRC Press. (in the Press.)

Cochrane, A. H., Nussenzweig, R. S. \& Nardix, E. H. (1980). Immunization against sporozoites. In Malaria, vol. 3, (ed. J. P. Kreier), pp. 163-202. New York: Academic Press.

Coevgniet, E. (1979). Thrombocyte migration inhibitory activity of Concanavalin A-stimulated human lymphocytes. In vivo and in vitro modifications by dipyridamole and acetylsalicylic acid. Thrombosis Research 15, 297-307.

Contreras, C. E., June, C. H., Perrin, L. H. \& Lambert, P. H. (1980). Immunopathological aspects of Plasmodium berghei infection in five strains of mice. I. Immune complexes and other serological features during the infection. Clinical and Experimental Immunology 42, 403-11.

Daye, J. B., Williams, J. L., McCetchan, T. F., Weber, J. L., Wirtz, R. A., Hockmeyer. W. T. Maloy, W. L., Haynes, J. D., Schneider, I., Roberts, D., Sanders, G. S., Reddy, E. P., Diggs, C. L. \& Miller, L. H. (1984). Structure of the gene encoding the immunodominant surface antigen on the sporozoite of the human malaria parasite Plasmodium falciparum. Science 225, 593-9.

Del Gitdice, G., Verdini, A. S., Pinori, M., Pessi, A., Verhaye, J.-P., Tougne, C.. Ivanoff, C. Lambert, P.-H. \& Evgers, H. D. (1986a). Detection of human antibodies against Plasmodium falciparum sporozoites using synthetic peptides. Journal of Clinical Microbiology 25, (in the Press).

Del Gicdice, G., Engers, H. D., Tougne, C., Biro, S. S., Weiss, N., Verdini, A. S., Pessi, A.. Degremont, A. A., Freyvogel, T. A.. Lambert, P.-H. \& Tanner, M. (1986b). Antibodies to the repetitive epitope of Plasmodium falciparum circumsporozoite protein in rural Tanzanian community : a longitudinal study of 132 children. American Journal of Tropical Medicine and Hygiene 36, (in the Press).

Del Gifdice, G., Cooper, J. A., Merino, J., Verdini, A. S., Pessi, A., Togna, A. R., Evgers, H. D. Corradin, G. \& Lambert, P.-H. (1986c). The antibody response in mice to carrier-free synthetic polymers of Plasmodium falciparum circumsporozoite repetitive epitope is $\mathrm{I}-\mathrm{A}^{\mathrm{b}}$ restricted : implications for malaria vaccines. Journal of Immunology 137 (in the Press).

Dennis, L. H., Eichelberger, J. W., Inyax, M. M. \& Conrad, M. E. (1967). Depletion of coagulation factors in drug-resistant Plasmodium falciparum malaria. Blood 29, 713-21.

Depierrecx, M.. Hochmanx, A., Herrera, S. \& Lambert, P. H. (1986). Increased blood brain barrier permeability during cerebral malaria in rats. Correlation with immunological and histological features. Parasite Immunology (In the Press).

Drager-Dayal, R. \& Lambert, P. H. (1986). Plasmodial antigens implicated in the protective immune response. In Textbook of Malaria, (ed. I. McGregor and W. Wernsdorfer). Churchill Livingston. (In the Press).

Edington, G. M. (1967). Pathology of malaria in West Africa. British Medical Journal 1. 715-18.

Elliott, J., Lis, Y., Mizel, S., Bleackley, R., Harsish, D. \& Paetkat, V. (1984). Induction of interleukin 2 messenger RNA inhibited by Cyclosporin A. Science 226, 1439-41 
Exea. V., Ellis, J., Zavala, F., Arnot, D. E., Asanavich, A., Mastda, A., Quakyi, I. \& Nussexzweig, R. S. (1984). DNA cloning of Plasmodium falciparum circumsporozoite gene: amino acid sequence of repetitive epitope. Science $225,628-30$.

FAJARDO, L. F. (1973). Malarial parasites in mammalian platelets. Nature, London 243, 298.

FAJARDO. L. F. (1979). The role of platelets in infections. I. Observations in human and murine malaria. Archives of Pathology and Laboratory Medicine 103, 131-4.

Fajardo, L. F. \& Tallent, C. (1974). Malarial parasites within human platelets. Journal of the American Medical Association 229, 1205-7.

Fisley, R. W.. MaCkey, L. A. \& Lambert, P. H. (1982). Virulent P. berghei malaria: prolonged survival and decreased cerebral pathology in T cell-deficient nude mice. Journal of Immunology 129, 2213-18.

Gexgoziax, N. \& Rice. D. T. (1982). Antibody-dependent cellular cytotoxicity with platelets as the target cell: potential application to the study of immune thrombocytopenia. Clinical and Experimental Immunology 47, 431-6.

Graselli-Piperno, A.. Inaba, K. \& Steinman, R. (1984). Stimulation of lymphokine release from T lymphocytes. Requirement for mRNA synthesis and inhibition by Cyclosporin A. Journal of Experimental Medicine 160, 1792-802.

Grat. G. E., Piguet, P. F., Evgers, H. D., Louis, J. A., Vassalli, P. \& Lambert, P. H. (1986). $\mathrm{L3T4}^{+} \mathrm{T}$ lymphocytes play a major role in the pathogenesis of murine cerebral malaria. Journal of Immunology 137, 2348-54.

Good, M. F., Berzofsky, J. A., Maloy, W. L., Hayashi, Y., FeJit, N., Hockmeyer, N. T. \& Miller, L. H. (1986). Genetic control of the immune response in mice to a Plasmodium falciparum sporozoite vaccine. Widespread nonresponsiveness to single malaria $T$ epitope in highly repetitive vaccine. Journal of Experimental Medicine 164, 655-60.

Herold, K. C., Laxchi, D. W., Moldwix, R. L. \& Fitch, F. W. (1986). Immunosuppressive effects of Cyclosporin A on cloned T cells. Journal of Immunology 136, 1315-21.

Hoffiaj, S. L., Wistar, R. JR., Ballot, W. R., Hollingdale, M. R., Wirtz, R. A., Schneider, I., Marwoto, H. A. \& Hockmeyer, W. T. (1986). Immunity to malaria and naturally acquired antibodies to the circumsporozoite protein of Plasmodium falciparum. New England Journal of Medicine 315, 601-6.

Horstyajx, R. D., Dietrich, M., Bieszle, C. \& Rasche, H. (1981). Malaria-induced thrombocytopenia. Blut 42, 157-64.

Jertsalem, C., Polder, T., Wijers-Rocw, Heinen, U., Eling, W., Oscnkoya, B. O. \& Trinh, P. (1983). Comparative clinical and experimental study on the pathogenesis of cerebral malaria. Contributions to Microbiology and Immunology 7, 130-8.

Kelton. J. G. \& Gibboxs. S. (1982). Autoimmune platelet destruction: Idiopathic Thrombocytopenic Purpura. Seminars in Thrombosis and Haemostasis 8, 83-104.

Keltox, J. G., Keystone, J., Moore, J., Denomme, G., Tozman, E., Glynn, M., Neame, P. B. \& GACLDIE, J. (1983). Immune-mediated thrombocytopenia of malaria. Journal of Clinical Investigation $71,832-6$.

Kelton, J. G., Keystone, J., Proctor, E. \& Neame, P. (1980). Malaria-induced immune thromboertopenia. Sixteenth Congress of the International Society of Haematology, Abstract 1494.

Kxisely, M. H. (1961). The settling of sludge during life. First observations, evidences and significances. A contribution to the biophysies of disease. Acta Anatomica 44, 1-64.

Kronke. M., Leonard, W. J.. Depper, J. M., Aryca, S. K. \& Wong-Staal, F. (1984). Cyclosporin $A$ inhibits T-cell growth factor gene expression at the level of mRNA transcription. Proceedings of the National Academy of Sciences. CSA 81, 5214-18.

Larssox, E. L. (1980). Cyclosporin A and dexamethasone suppress T-cell responses by selectively acting at distinct sites of the triggering process. Journal of Immunology 124, 2828-33.

Loonestwax, S.. Wareell. D. A., White, X. J.. Sttharasamai, P., Chanthavanich, P., Sun-

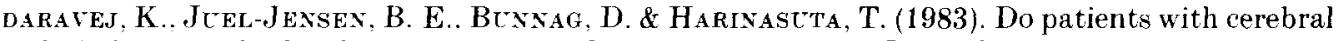
malaria have cerebral oedema? A computed tomography study. Lancet i, 434-7.

ICFARLANe. H. (1971). Cell-mediated immunity in protein calorie malnutrition. Lancet ii, 1146-7.

McINTYRe, K. R. \& Seidmax, J. G. (1984). Nucleotide sequence of mutant $1-A$ beta ${ }^{\mathrm{bm}} 2 \mathrm{~g}$ gene is evidence for genetic exchange between mouse immune response genes. Nature, London 308, 551-3.

IcMlrray. D. X. (1984). Cell-mediated immunity in nutritional deficiency. Progress in Food and Tutritional Sciences 8. 193-228.

McPhersox, G. G. Warrell, M. J., White, N. J.. Looarestwax, S. \& Warrell, D. A. (1985). 
Human cerebral malaria. A quantitative ultrastructural analysis of parasitized erythrocyte sequestration. American Journal of Pathology 119, 385-401.

Mazier, D., Mellotk, S., Bealdoin, R. L., Texier, B., Drullhe, P., Hockmeyer, W., Trosper, J., Pade, C., Charoenvit, Y., Young, J., Miltgen, F., Chedid, L., Chigot, J. P., Galley, B.. Brandicourt, O. \& Gentilini, M. (1986). Effect of antibodies to recombinant and synthetic peptides on P. falciparum sporozoites in vitro. Science 231, 156-9.

Nardin, E. H., Nussexzweig, R. S., McGregor, I. A. \& Bryan, J. H. (1979). Antibodies to sporozoites: their frequent occurrence in individuals in an area of hyperendemic malaria. Science 206, 597-9.

Nawroth, P. P., Bank, I., Handley, D., Cassimeris, J., Chess, L. \& Stern, D. (1986). Tumor necrosisfactor/cachectin interacts with endothelial cell receptors to induce the release of interleukin 1 . Journal of Experimental Medicine 163, 1363-75.

Nickell, S. P., Scheibel, L. W. \& Cole, G. A. (1982). Inhibition by Cyclosporin A of rodent malaria in vivo and human malaria in vitro. Infection and Immunity 37, 1093-100.

Nussenzweig, V. \& Nussenzweig, R.S. (1985). Circumsporozoite proteins of malaria parasites. Cell 42, 401-3.

Ockenhorse, C. F., Schllmax, S. \& Shear, H. L. (1984). Induction of crisis form in the human malaria parasite Plasmodium falciparum by gamma-interferon-activated, monocyte-derived macrophages. Journal of Immunology 133, 1601-8.

Polder, T., Jercsalem, C. \& Eling, W. (1983). Topographical distribution of the cerebral lesions in mice infected with Plasmodium berghei. Tropenmedizin und Parasitologie 34, 235-43.

Rest, J. R. (1982). Cerebral malaria in inbred mice. I. A new model and its pathology. Transactions of the Royal Society of Tropical Medicine and Hygiene 76, 410-15.

REST, J. R. \& WRIGHT, D. H. (1979). Electron microscopy of cerebral malaria in golden hamsters (Mesocricetus auratus) infected with Plasmodium berghei. Journal of Pathology 127, 115-20.

Rosesberg, Y. J. (1978). Autoimmune and polyclonal B-cell responses during murine malaria. Nature. London 274, 170-2.

SCHWARTZ, R. H. (1986). Immune response genes (Ir) genes of the murine major histocompatibility complex. Advances in Immunology 38, 31-201.

Sheagrex, J. N., Tobie, J. E., Fox, L. M. \& Wolfe, S. M. (1970). Reticulo-endothelial sustem phagocytic function in naturally acquired human malaria. Journal of Laboratory and Clinical Medicine 75, 481-7.

Shevach, E. M. (1985). The effects of Cyclosporin A on the immune system. Annual Revieu in Immunology 3, 397-423.

Skcdowitz, R. B., Katz, J., Lcrie, A., Levis, J. \& Metz, J. (1973). Mechanisms of thrombocytopenia in malignant tertian malaria. British Medical Journal 2, 515-47.

Srichaiktl, T., Prwasatiex, P., Karsjanajetanee, J. \& Bokisch, V. A. (1975). Complement changes and disseminated intravascular coagulation in Plasmodium falciparum malaria. Lancet $\mathbf{i}$, 770-2.

Tapchaisri. P., Chomcharn, Y.. Poonthong, C., Asavanich, A., Limslwan, S., Maleevax, O. TharavaniJ, S. \& Harinaseta, T. (1983). Anti-sporozoite antibodies induced by natural infection. American Journal of Tropical Medicine and Hygiene 32, 1203-8.

Тноммеx-Scotт. K. (1981). Antimalarial activity of Cyclosporin A. Agents and Actions 11, 770-3.

Togna, A. R., Det Gutcice, G., Verdini, A., Bonelli, F., Pessi, A., Engers, H. D. \& Corradis. G. (1986). Synthetic P. falciparum circumsporozoite peptide elicit heterogenous $\mathrm{L} 3 \mathrm{~T} 4^{+} \mathrm{T}$ cell proliferative responses in $\mathrm{H}-2^{\mathrm{b}}$ mice. Journal of Immunology 137 (in the Press).

Toro. G. \& Romax, G. (1978). Cerebral malaria. A disseminated vasculomyelinopathy. Archives of Neurology 35. 271-5.

Vrekex. J., Cremer-Goote, T. M. (1978). Haemostatic defect in non-immune patients with falciparum malaria: no evidence of diffuse intravascular coagulation. British Medical Journal 2, 533-5.

WAsh. A. C. (1979). Cerebral malaria (letter). Archives of Neurology 36, 119.

Watrs, T. (1969). Thymus weights in malnourished children. Journal of Tropical Pediatrics 15, 15̃-8.

Wilson. J. J., Neame. P. B. \& Kelton, J. G. (1982). Infection-induced thrombocytopenia. Seminars in Thrombosis and Haemostasis 8. 217-33.

Wiskocil. R.. Weiss, A.. Imbodex. J.. Kayin-Lewis, R. \& Stobo, J. (1985), Activation of a human T-cell line: a two-stimulus requirement in the pretranslational events involved in the coordinate expression interleukin 2 and interferon- $\gamma$ genes. Journal of Immunology 134, 1599-603. 
Wright, I). H., MaSfMBE, R. M. \& Bazira, E. R. (1971). The effect of antithymocyte serum on golden hamsters and rats infected with Plasmodium berghei. British Journal of Experimental Pathology $\mathbf{5 2}$, $465-77$.

Yoeli. M. \& Hargreaves, B. J. (1974). Brain capillary blockage produced by a virulent strain of rodent malaria. Science $\mathbf{1 8 4}, \mathbf{5 7 2 - 3}$.

Young. J. F., Hockmeyer. W. T., Gross, M., Ballod, W. R., Wirtz, R. A., Trosper, G. H., Beatdoin, R. L., Holdingdale, M. R., Miller, L. H., Diggs, C. L. \& Rosenberg, M. (1985). Expression of Plasmodium falciparum circumsporozoite proteins in Escherichia coli for potential use in a human malaria vaccine. Science $228,95862$.

Zavala. F.. Cochrane, A. H. Nardin, E. H., Nussenzweig, R. S. \& Nussenzweig, V. (1983). Circumsporozoite proteins of malaria parasites contain a single immunodominant region with two or more identical epitopes. Journal of Experimental Medicine 157, 1947-57.

Zayala, F., Tay, J. P., Hollingdale, M. R., Cochrane, A. H., Quakyi, I., Nessenzweig, R. S. \& Nussenzweig, V. $(1985 b)$. Rationale for development of a synthetic vaccine against Plasmodium falciparum malaria. Science 228, 1436-40.

Zavala, F. TAM, J. P.\& Mastod, A. (1986). Synthetic peptides for the detection of humoral immunity of Plasmodium falciparum sporozoites. Journal of Immunological Methods 93, 55-61.

Zavala. F., Tam. J. P., Nussenzweig, R. S. \& Nussenzweig, V. (1985a). The epitope specificity of anti-P. falciparum sporozoite antibodies present in human sera from endemic areas. Federation Proceedings 44, 980. 